\title{
RISING CHINA AND WORLD ORDER
}


This page intentionally left blank 


\section{RISING CHINA AND WORLD ORDER}

\section{Zhang Yunling}

Chinese Academy of Social Sciences, China

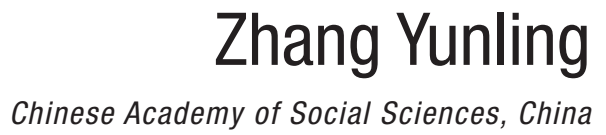


Published by

World Scientific Publishing Co. Pte. Ltd.

5 Toh Tuck Link, Singapore 596224

USA office: 27 Warren Street, Suite 401-402, Hackensack, NJ 07601

UK office: 57 Shelton Street, Covent Garden, London WC2H 9HE

\section{British Library Cataloguing-in-Publication Data}

A catalogue record for this book is available from the British Library.

\section{RISING CHINA AND WORLD ORDER}

Copyright () 2010 by World Scientific Publishing Co. Pte. Ltd.

All rights reserved. This book, or parts thereof, may not be reproduced in any form or by any means, electronic or mechanical, including photocopying, recording or any information storage and retrieval system now known or to be invented, without written permission from the Publisher.

For photocopying of material in this volume, please pay a copying fee through the Copyright Clearance Center, Inc., 222 Rosewood Drive, Danvers, MA 01923, USA. In this case permission to photocopy is not required from the publisher.

ISBN-13 978-981-4304-21-4

ISBN-10 981-4304-21-2

Typeset by Stallion Press

Email: enquiries@stallionpress.com

Printed in Singapore. 


\section{Contents}

Foreword vii

1. New Security Thinking for China in a Changing World 1

2. Searching for Collaboration: China and the US in the Asia-Pacific

3. Regional and Global Dimensions in the China-US Relationship

4. China and its Neighbors: Relations in a New Context 60

5. Changing Sino-US-Japanese Relations 79

6. Peace in the Korean Peninsula and the Role of China 98

7. Ending Confrontation in the Korean Peninsula: The Way Out

8. The International Environment Facing China in the Asia-Pacific Region

9. How to Make Our Region Safe

10. Non-Traditional Security and Socio-Economic Development of East Asia

11. Whither the World Order?

12. We Need a New World Order 
This page intentionally left blank 


\section{Foreword}

China has achieved great success since conducting the policy of reform and opening up to the outside world. Within only three decades, the main indicators of China's economy, excluding GDP/per capita, are taking the lead in world. For example, its foreign exchange reserve is No. 1, its foreign trade is No. 2, and its GDP is No. 3 (and may soon be No. 2 after the US) in the world. Based on its economic rise, China's "comprehensive power" has been significantly enhanced.

China's growth is one of the most important events in today's global development. A rising China has brought about many new challenges both to itself and to the world. China, as a developing country that is fast transitioning, has to manage stable and balanced economic, political, and social development and change internally, while developing peaceful and cooperative relations with the major powers, its close neighbors and the rest of the world at the same time. China has adopted a dual strategy: promoting harmony both in the country (harmonious society) and in the world (harmonious world). The core objective of this harmony is to ensure a stable "grand transformation" inside the country while, at the same time, ensuring peace and cooperation internationally. This is not just a propaganda slogan, but a strategy with real efforts made to address China's central interests - realizing its dream of turning China into a modern and advanced country by the mid-21st century.

The end of the Cold War brought about a changed world order, and fundamental challenges to China since it is one of the only few countries in the post-Cold War world that continues the socialist system as led by the Chinese Communist Party. In the face of NATO's action in the Balkan region, China strongly opposed the 
so-called "new interventionalism" and rejected the "new world order" as labeled by the US. China has been worried that the US and its Western alliance might take action to force it to change its political system and create disorder. However, China did not take a confrontational approach. Instead, China kept its door open and made great efforts to reshape the trend and structure of world development by making all kinds of partnerships with major powers and other countries, especially with its close neighbors. Although the world today is still not entirely peaceful, China's new efforts have contributed significantly to world order by preventing the post-Cold War world from turning into a newly divided and confrontational one.

Among all the relations that China deals with, its relations with the US is the most sensitive, complex and delicate since the US is the only superpower left and has great power to change and even dominate the region and the world. As an emerging power, China benefits from participating in the existing global system and tries to play its role in regional and global affairs within the system. Thus China becomes a "stakeholder", rather than a "destroyer" of the current system. In developing relations with the US, China has adopted a pragmatic policy aimed at "avoiding confrontation and developing cooperation" which has helped to nurture a "cooperative partnership" between the two sides. Increasing economic integration based on large trade and investment flows and other emerging shared interests in regional and global affairs have made the two countries move to more realistic approaches and policies in handling their complex relations. Dialogue, consultation and cooperation, rather than confrontation have become the major trend.

China is a unique country in the world in having many neighboring countries both land-based and in the surrounding sea. Relations with its neighbors are very complex, some of which are due to historical legacies, while others are due to current disputes over border line demarcations, ownership of the islands in the South China Sea and East China Sea, as well as the newly emerging exclusive economic zones (EEZ). China has carefully and skillfully handled neighboring relationships in three ways: proposing to lay aside the disputes and to develop cooperation; settling border line demarcations through 
negotiations; as well as developing regional cooperation which helps to create common frameworks for working together. Although some problems still remain, in general, the surrounding areas are stable and cooperative, which helps greatly to ensure a peaceful environment for China.

China's rise is a new and important phenomenon in today's and future world development. A rising China and a changing world are two parallel trends that characterize our life. For China, the challenges are enormous both domestically and internationally. However, being a responsible big power, China has no intention to overturn the current global system or create a new world order in which it dominates, though it will make efforts to reshape the transition and change of the current order to a more reasonable and balanced one.

As the Director of the Institute of the Asia-Pacific Studies, Chinese Academy of Social Sciences, I have had to engage in many studies and discussions on China's regional and global relations in the past 15 years. The articles that are included in this book are part of my writings relating to the research projects and conferences on China's foreign policy and foreign relations, which could help people to understand China's rise, China's interests and China's policies, etc.

My gratitude goes to World Scientific Publishing Co. who encouraged me to collect these articles and agreed to publish them as a book. 